\title{
Ethanol Feeding Inhibits Proinflammatory Cytokine Expression from Murine Alveolar Macrophages Ex Vivo
}

\author{
Theodore J. Standiford and Jean M. Danforth
}

\begin{abstract}
The prolonged and excessive consumption of alcohol has been shown to predispose the host to a variety of infectious complications, which may be due, in part, to the inability to produce important activating and chemotactic cytokines. In this study, we assessed the effect of alcohol ingestion on the expression of tumor necrosis factor- $\alpha$ (TNF- $\alpha$ ), and the chemokines macrophage inflammatory pro-

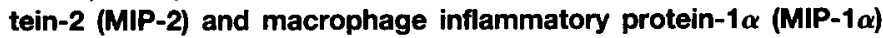
from murine alveolar macrophages (AMs) cultured ex vivo. Twoweek ethanol feeding resulted in substantial impairment in the lipopolysaccharide (LPS)-induced expression of TNF- $\alpha$, MIP-2, and MIP-1 $\alpha$ mRNA, and protein from LPS-stimulated AMs, compared with cytokine production from AMs obtained from CD-1 mice receiving an isocaloric control diet. These findings indicate that ethanol feeding results in diminished production of chemotactic and/or activating cytokines from AMs ex vivo that may contribute to the impairment in lung inflammatory responses and antimicrobial host defense that is observed in the setting of alcohol ingestion/intoxication clinically and experimentally.
\end{abstract}

Key Words: Tumor Necrosis Factor- $\alpha$, Chemokines, Alcohol, Alveolar Macrophages, Cytokines.

$\mathbf{H}$ OST DEFENSE against lung pathogens requires the accumulation and activation of leukocytes, including neutrophils and mononuclear phagocytes, at the site of microbial invasion. ${ }^{1}$ Resident alveolar macrophages (AMs) are believed to play a critical role in the process of leukocyte recruitment/activation via the elaboration of important activating and chemotactic cytokines. ${ }^{2}$ Tumor necrosis factor- $\alpha$ (TNF- $\alpha$ ) is one such cytokine produced by activated AMs that directly activates leukocyte microbicidal activity, and can mediate lung polymorphonuclear influx by upregulating leukocyte adhesion molecules and by serving as an afferent signal in the autocrine or paracrine induction of chemotactic molecules. ${ }^{3}$ AMs are also rich cellular sources of chemokines. ${ }^{4}$ The C-X-C chemokine family, which includes macrophage inflammatory protein-2 (MIP-2), exerts predominant neutrophil chemotactic and activating effects, whereas $\mathrm{C}-\mathrm{C}$ chemokines-including macrophage inflammatory protein-1 $\alpha$ (MIP-1 $\alpha$ )-are chemotactic for mono-

From the Departments of Medicine, Division of Pulmonary and Critical Care Medicine, the University of Michigan Medical School, Ann Arbor, Michigan.

Received for publication February 21, 1997; accepted June 2, 1997

This research was supported in part by the National Institutes of Health Grants AA10571, HL58200, and HL57243.

Reprint requests: Theodore J. Standiford, M.D., Department of Internal Medicine, Division of Pulmonary and Critical Care Medicine, the University of Michigan Medical Center, 3916 Taubman Center, Box 0360, Ann Arbor, MI 48109-0360.

Copyright $(1997$ by The Research Society on Alcoholism. 1212 nuclear cells and eosinophils. ${ }^{5-7}$ TNF- $\alpha$, as well as several members of the chemokine family, have been shown to be required for effective host defense against a variety of pulmonary pathogens. ${ }^{8-12}$ The induction of TNF- $\alpha$, MIP-2, and MIP- $1 \alpha$ gene expression in response to endotoxin requires the binding of a trans-NF- $\kappa \mathrm{B}$ binding protein to the $\mathrm{NF}-\kappa \mathrm{B}$ DNA binding site, resulting in enhanced proinflammatory cytokine gene expression. . $^{13,14}$

The prolonged and excessive consumption of alcohol predisposes the host to a variety of infectious complications, in particular bacterial infections of the lung. ${ }^{15,16}$ The alcohol-induced impairment in lung antimicrobial host defense is believed to be due, in part, to the inability to produce important activating and chemotactic cytokines. Specifically, the acute, but not chronic infusion of alcohol, has been shown to attenuate lipopolysaccharide (LPS)induced increases in serum TNF- $\alpha .{ }^{17-20}$ In addition, alcohol inhibits the induction of TNF- $\alpha$ detected in bronchoalveolar lavage (BAL) fluid after the intratracheal administration of LPS or live bacterial organisms. ${ }^{19}$ The incubation of AMs with alcohol in vitro suppresses the production of murine macrophage-derived interleukin (IL)-6 production, ${ }^{21}$ whereas prolonged alcohol feeding significantly inhibits the expression of interferon- $\gamma$ and soluble IL-2 receptor from retroviral-infected murine splenocytes. $^{22}$ These studies indicate that alcohol exposure globally suppresses the ability of immune cells to express leukocyte activating cytokines. Molecular mechanisms by which alcohol mediates this effect have not been characterized.

In this study, we assessed the effect of chronic alcohol consumption ( 2 weeks) on the expression of TNF- $\alpha$, MIP-2, and MIP- $1 \alpha$ from resting and LPS-stimulated AMs ex vivo. We have chosen to study these cells ex vivo, because these conditions allow for cells to be recovered and studied in pure populations, while closely reproducing the conditions of in vivo alcohol exposure.

\section{MATERIALS AND METHODS}

\section{Reagents}

Murine recombinant TNF- $\alpha$, MIP-2, and MIP- $1 \alpha$ were purchased from R\&D Systems (Minneapolis, MN). Polyclonal antimurine TNF- $\alpha$, MIP-2, and MIP- $1 \alpha$ antiserum used in our ELISA were produced by immunization of rabbits with recombinant murine cytokines in multiple intradermal sites with complete Freund's adjuvant. Stock LPS (Sigma Chemical Co., St. Louis, MO) was prepared at a concentration of $200 \mu \mathrm{g} / \mathrm{ml}$ in sterile 
RPMI-1640 (Whitaker Biomedical Products, Whitaker, CA) containing 1 $\mathrm{mM}$ glutamine, $25 \mathrm{mM}$ HEPES, $100 \mathrm{units} / \mathrm{ml}$ penicillin, and $100 \mu \mathrm{g} / \mathrm{ml}$ streptomycin (Hazelton Research Products, Denver, PA) (complete media).

\section{Protocol for Alcohol Feeding}

To assess the effects of alcohol on the expression and regulation of proinflammatory cytokines, two groups of 6- to 8-week-old female CD-1 mice received calorie-matched complete liquids diets (Bioserve, Frenchtown, $\mathrm{NJ}$ ), with the alcohol-fed animals receiving incremental increases in ethanol content in their diet as follows: ethanol $2.2 \%(\mathrm{v} / \mathrm{v}) \times 4$ days; then $4.4 \% \times 4$ days, then $6.6 \% \times 6$ days, for a total of 14 days of alcohol feeding. Serum ethanol levels were determined in the Clinical Toxicology Laboratory at the University of Michigan Hospital by gas chromatography. The ethanol level in alcohol-fed animals at the end of this period was $166.9 \pm 19.4 \mathrm{mg} / \mathrm{dl}$ (range: 5.9 to $398.4 \mathrm{mg} / \mathrm{dl}$ ). During the 2-week caloriematched diet, the control mice gained $2.00 \pm 0.18 \mathrm{~g}$, whereas ethanol-fed animals lost $0.99 \pm 0.15 \mathrm{~g}$.

\section{Isolation of Murine AMs}

CD-1 mice (Charles River Breeding Laboratories, Cambridge, MA) were maintained under specific pathogen-free conditions. The mice were then anesthetized and exsanguinated. BAL was performed to obtain AMs. ${ }^{4}$ Before BAL, the pulmonary vasculature was perfused with $1 \mathrm{ml}$ of phosphate-buffered saline (PBS) via the right ventricle. The trachea was then exposed and intubated using a $1.7 \mathrm{~mm}$ o.d. polyethylene catheter. BAL was performed by instilling PBS containing $5 \mathrm{mM}$ EDTA in $1-\mathrm{ml}$ aliquots. Approximately $10 \mathrm{ml}$ of lavage fluid was retrieved per mouse, resulting in the isolation of 5 to $7 \times 10^{5} \mathrm{AMs} /$ mouse. The BAL fluid from mice was pooled. The AMs were washed using complete media, followed by cell counts and differential cell analysis. BAL cell differentials consisted of $>97 \%$ AMs in both control and ethanol-fed animals. AM viability was $>95 \%$ by trypan blue exclusion. $2 \times 10^{5} \mathrm{AMs} / 200 \mu \mathrm{l}$ were adherencepurified per well of a 96-well culture plate for protein analysis. For total RNA isolation, $1 \times 10^{6} \mathrm{AMs} / 1 \mathrm{ml}$ were adherence-purified for each 35 $\mathrm{mm}$ culture plate.

\section{Cytokine ELISAS}

Extracellular immunoreactive murine TNF- $\alpha$, MIP-2, and MIP-1 $\alpha$ was quantitated using a modification of a double ligand method as previously described. ${ }^{9,10}$ Briefly, flat-bottomed 96-well microtiter plates (Nunc Immuno-Plate I 96-F, Denmark, Netherlands) were coated with $50 \mu \mathrm{l} /$ well of rabbit antimurine TNF- $\alpha$, MIP-2, or MIP- $1 \alpha$ antibody $(1 \mu \mathrm{g} / \mathrm{ml}$ in $0.6 \mathrm{M}$ $\mathrm{NaCl}, 0.26 \mathrm{M} \mathrm{H}_{3} \mathrm{BO}_{4}$, and $0.08 \mathrm{~N} \mathrm{NaOH}$; $\mathrm{pH} \mathrm{9.6)} \mathrm{for} 16 \mathrm{hr}$ at $4^{\circ} \mathrm{C}$ and then washed with PBS (pH 7.5):0.05\% Tween-20 (wash buffer). Microtiter plate nonspecific binding sites were blocked with $2 \%$ bovine serum albumin in PBS and incubated for $90 \mathrm{~min}$ at $37^{\circ} \mathrm{C}$. Plates were rinsed four times with wash buffer, and diluted (neat and 1:10) cell-free supernatants $(50 \mu \mathrm{l})$ in duplicate were added, followed by incubation for $1 \mathrm{hr}$ at $37^{\circ} \mathrm{C}$. Plates were washed four times, followed by the addition of $50 \mu \mathrm{l} /$ well biotinylated rabbit anti-TNF- $\alpha$, MIP-2, or MIP- $1 \alpha$ antibody $[3.5 \mu \mathrm{g} / \mathrm{ml}$ in PBS (pH 7.5), $0.05 \%$ Tween-20, and $2 \%$ fetal calf serum], and plates incubated for $30 \mathrm{~min}$ at $37^{\circ} \mathrm{C}$. Plates were washed four times, streptavidinperoxidase conjugate (Vector Laboratories, Burlingame, CA) added, and the plates incubated for $30 \mathrm{~min}$ at $37^{\circ} \mathrm{C}$. Plates were again washed four times and chromogen substrate (Vector) added. The plates were then incubated at room temperature to the desired extinction, and the reaction terminated with $50 \mu \mathrm{l} /$ well of $3 \mathrm{M} \mathrm{H}_{2} \mathrm{SO}_{4}$ solution. Plates were read at 490 $\mathrm{nm}$ in an ELISA reader. Standards were $1 / 2 \log$ dilutions of recombinant murine TNF- $\alpha$, MIP-2, or MIP- $1 \alpha$ from $1 \mathrm{pg} / \mathrm{ml}$ to $100 \mathrm{ng} / \mathrm{ml}$. This ELISA method consistently detected murine TNF- $\alpha$, MIP-2, and MIP- $1 \alpha$ concentrations above $25 \mathrm{pg} / \mathrm{ml}$ and did not cross-react with IL-1, IL-2, IL-4, IL-6, or interferon- $\boldsymbol{\gamma}$. In addition, the ELISA did not cross-react with other members of the murine chemokine family, including murine KC, ENA-78, MCP-1, and murine MIP- $1 \beta$.

\section{Northem Blot Analysis}

Total cellular RNA from AMs was isolated using a modification of Chirgwin et al. ${ }^{23}$ Briefly, cells were overlaid with $1 \mathrm{ml}$ of a solution consisting of $25 \mathrm{mM}$ Tris ( $\mathrm{pH} 8.0$ ), containing $4.2 \mathrm{M}$ guanidine isothiocyanate, $0.5 \%$ Sarkosyl, and $0.1 \mathrm{M} 2$-mercaptoethanol. After homogenization, the above suspension was added to an equal volume of $100 \mathrm{mM}$ Tris ( $\mathrm{pH} 8.0$ ), containing $10 \mathrm{mM}$ EDTA and $1.0 \%$ sodium dodecyl sulfate. The mixture was then extracted with chloroform-phenol and chloroformisoamyl alcohol. The RNA was alcohol-precipitated and the pellet dissolved in DEPC $\mathrm{H}_{2} \mathrm{O}$. RNA was separated by Northern blot analysis using formaldehyde, $1 \%$ agarose gels, transblotted to nitrocellulose, baked, prehybridized, and hybridized with a ${ }^{32} \mathrm{P} 5^{\prime}$-end-labeled oligonucleotide probe. The murine TNF- $\alpha$ oligonucleotide probe used had the sequence 5'-GTC-CCC-CTT-CTC-CAG-CTG-GAA-GAC-TCC-TCC-3', the murine MIP-2 oligonucleotide probe had the sequence 5 -GTG-GGC-TTCACA-CTT-CAC-AGT-TAC-3', and the MIP- $1 \alpha$ oligonucleotide probe had the sequence 5'-GAA-GCA-GCA-GGC-AGT-CGG-GGT-GTCAGC-TCC- $3^{6}{ }^{6,7}$ In addition, a ${ }^{32} \mathrm{P}$-labeled oligonucleotide probe for $\beta$ actin with the sequence 5'-CCA-AAG-CGC-TCC-ATG-GCC-TCC-3' was used as a control. Blots were washed and autoradiographs quantitated by video densitometry using a Javelin chromachip camera (Javelin Electronics, Torrance, CA) interfaced with a Macintosh II computer containing an Image Capture 1000 frame grabber (Scion Corp., Walkersville, MD) and image 1.40 software (NIH Public Software, Bethesda, MD). Equivalent amounts of total RNA/well were assessed by monitoring $28 \mathrm{~S}$ and 18 S ribosomal RNA.

\section{Statistical Analysis}

Data were analyzed by a Macintosh II computer using Statview II statistical package (Abacus Concepts, Inc., Berkeley, CA). Data are expressed as mean \pm SEM and compared using a two-tailed Student's $t$ test. Data were considered statistically significant if $p$ values were $<0.05$.

\section{RESULTS}

Effect of Ethanol Feeding on TNF- $\alpha, M I P-2$, and MIP-1 $\alpha$ Expression from Murine AMs Ex Vivo

Because AMs are the chief immune effector cells of the lung airspace, ${ }^{2}$ we assessed the effect of alcohol feeding on the expression of proinflammatory cytokines from murine AMs ex vivo. AMs were harvested from control and alcohol-fed mice, adherence-purified for $1 \mathrm{hr}$, challenged with various doses of LPS, and supernatants harvested after 24 $\mathrm{hr}$ in culture. This time point was chosen, as maximal accumulation of cytokines is observed at $24 \mathrm{hr}$ post-LPS stimulation. As shown in Fig. 1, unstimulated AMs obtained from control mice produced low levels of TNF- $\alpha$ and MIP- $1 \alpha$, and moderate levels of MIP-2, whereas cells treated with graded doses of LPS from $100 \mathrm{ng}$ to $10 \mu \mathrm{g} / \mathrm{ml}$ expressed substantial quantities of these cytokines in a dose-dependent fashion. Interestingly, AMs obtained from ethanol-fed mice expressed significantly less TNF when stimulated with maximal levels of LPS $(10 \mu \mathrm{g} / \mathrm{ml})$, whereas AMs obtained from ethanol-fed mice expressed significantly less MIP-2, and MIP- $1 \alpha$ when stimulated with both 1 and $10 \mu \mathrm{g} / \mathrm{ml}$ LPS. Maximally, cells isolated from ethanolfed mice challenged with $10 \mu \mathrm{g}$ LPS producing $38.2 \%$, $61.3 \%$, and $43 \%$ less TNF- $\alpha$, MIP-2, and MIP- $1 \alpha$, compared with similar numbers of AMs obtained from control animals. Interestingly, the effect of ethanol feeding was 


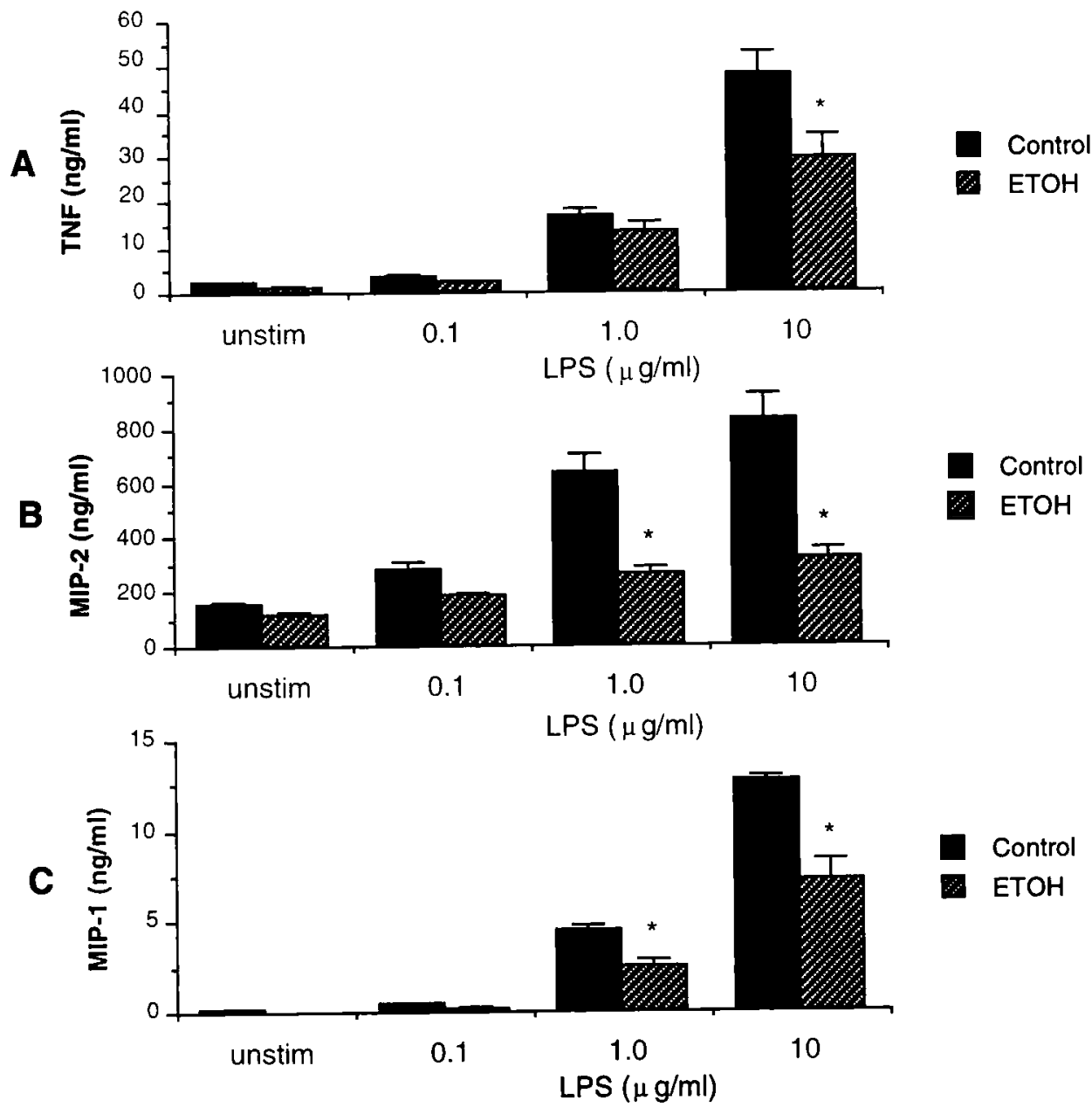
Fig. 1. TNF- $\alpha$, MIP-2, and MIP-1 $\alpha$ produc-
tion from LPS-stimulated AMs after $24 \mathrm{hr}$ in
culture. " $\rho<0.05$, compared with AMs from
control-fed mice. Experimental, $n=10-12$
per condition. ETOH, ethanol; unstim, un-
stimulated. reversible, as the expression of TNF- $\alpha$ and chemokines from LPS-treated AMs returned to control levels when alcohol feeding was discontinued for 7 days postethanol feeding (data not shown). These data indicate that ethanol feeding results in a marked reduction in the ability of AMs to express important activating and chemotactic cytokines in response to exogenous stimuli, and this inhibitory effect of alcohol is maintained even when these cells are removed from the environment of in vivo alcohol exposure.

\section{Effect of Ethanol Feeding on TNF- $\alpha, M I P-2$, and MIP-1 $\alpha$} mRNA Expression from Murine AMs Ex Vivo.

To examine the molecular level at which alcohol suppressed proinflammatory cytokine expression from endotoxin-challenged AMs, we assessed TNF- $\alpha$, MIP-2, and MIP-1 $\alpha$ mRNA levels from AMs obtained from control and ethanol-fed animals after $4 \mathrm{hr}$ in culture. This time point was chosen because maximal accumulation of chemokine mRNA is observed at that time point in vitro, whereas TNF- $\alpha$ mRNA continues to be expressed in high levels at 4 hr post-LPS stimulation. Both the constitutive and LPSinduced expression of TNF- $\alpha$ (Fig. 2) and MIP-1 $\alpha$ (Fig. 3) mRNA were markedly reduced, compared with cytokine
mRNA expression from control AMs. Whereas the constitutive expression of MIP-2 mRNA was not altered by ethanol feeding, the LPS-induced expression of MIP-2 levels was diminished, compared with that observed in control AMs (Fig. 4). Maximally, steady-state levels of TNF- $\alpha$, MIP- $1 \alpha$, and MIP-2 mRNA from ethanol-exposed AM were $47 \%, 51 \%$, and $48 \%$ less than steady-state mRNA levels in control AM, respectively.

\section{DISCUSSION}

Alcohol exposure has previously been shown to result in significant impairment in inflammatory cytokine expression. The incubation of murine peritoneal macrophages in $1 \% \mathrm{v} / \mathrm{v}$ ethanol in vitro inhibited the LPS-induced production of IL- $6 .{ }^{20}$ In vivo acute alcohol intoxication resulted in significant attenuation of TNF- $\alpha$ release in response to either endotoxin or intrapulmonary challenge with Klebsiella pneumoniae. ${ }^{17,18}$ In contrast, the chronic administration of ethanol (6 weeks) had either no effect or actually enhanced the peak expression of serum TNF- $\alpha$ postendotoxin administration. ${ }^{18,19}$ Our study is the first to examine the effect of in vivo alcohol feeding on the ability of pure populations of AMs to express important proinflammatory 
A

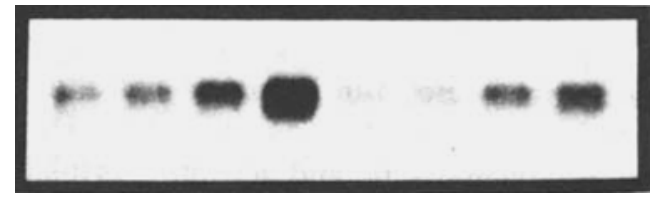

.

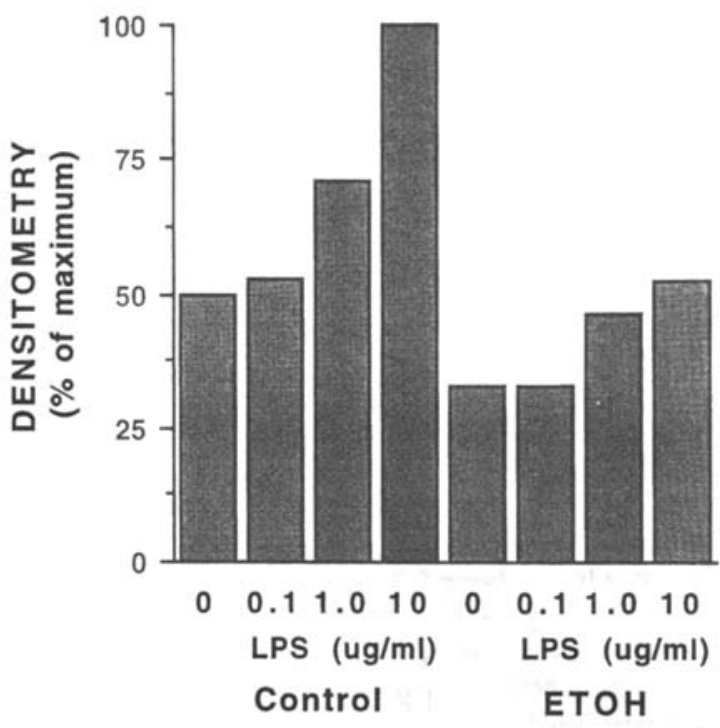

C

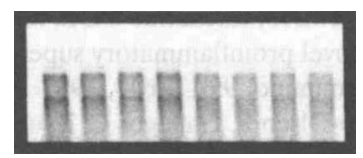

Fig. 2. Representative Northern blot analysis depicting the effect of ethanol on steady-state levels of TNF- $\alpha$ mRNA from unstimulated and LPS-stimulated AMs. (A) Autoradiogram of TNF mRNA expression. (B) Densitometric quantification of the corresponding autoradiogram. (C) The 28s and 18s rRNA demonstrating equivalent loading of RNA. ETOH, AMs from ethanol-fed animals. Experimental, $n=2$.

cytokines ex vivo. Two-week alcohol feeding resulted in significant inhibition of AM TNF- $\alpha$ mRNA and protein expression in response to LPS, with cells demonstrating a relative insensitivity to LPS, compared with control AMs. In addition, we observed a marked inhibition of C-X-C and $\mathrm{C}-\mathrm{C}$ chemokine expression in AMs from alcohol-fed mice in a fashion similar to that observed with TNF- $\alpha$. It is of interest that the suppressive effects observed after 2-week exposure to alcohol was similar to that observed in acute ethanol intoxication, ${ }^{17,18}$ rather than the enhancing effects observed after chronic alcohol ingestion. ${ }^{20}$ Furthermore, our data suggest that AMs are susceptible to reversible alcohol suppressive effects, and the observed impairment in TNF production in the airspace of acutely ethanol-intoxicated animals challenged with $K$. pneumoniae ${ }^{19}$ is likely due to impairment in TNF production from AMs.

The molecular mechanism(s) by which alcohol suppresses macrophage-derived cytokine production had not previously been defined. Our studies indicate that alcohol feeding suppresses cytokine mRNA levels from endotoxinstimulated AMs, indicating that the effects of ethanol occur as a result of decreased mRNA synthesis and/or acceler-

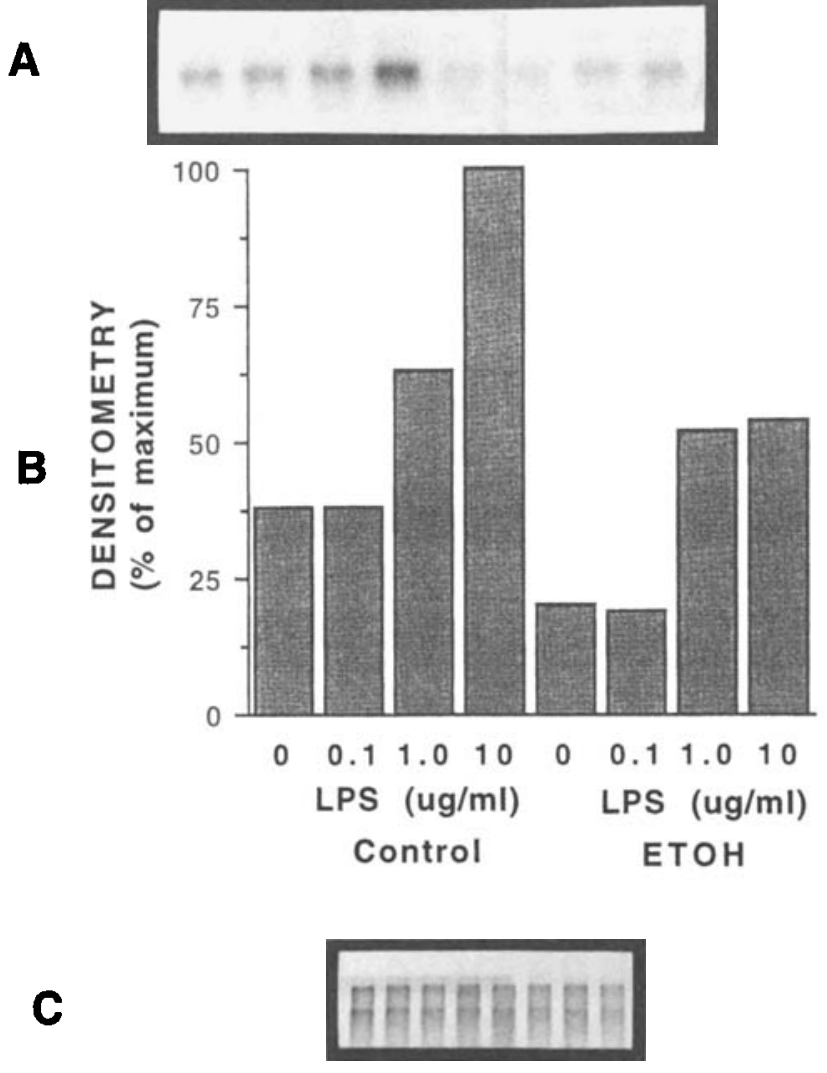

Fig. 3. Representative Northern blot analysis depicting the effect of ethanol on steady-state levels of MIP-1 $\alpha$ mRNA from unstimulated and LPS-stimulated AM. (A) Autoradiogram of MIP-1 $\alpha$ mRNA expression. (B) Densitometric quantification of the corresponding autoradiogram. (C) The $28 \mathrm{~s}$ and 18s rRNA demonstrating equivalent loading of RNA. ETOH, AMs from ethanol-fed animals. Experimental, $n=2$.

ated mRNA degradation. Preliminary studies in our laboratory using gel shift analysis suggest that nuclear NF- $\mathrm{B}$ activity is attenuated in LPS-treated AMs from alcohol-fed mice, compared with control AMs. Indeed, impaired NF- $\kappa$ B activity would account for diminished LPS-induced synthesis of TNF- $\alpha$, MIP-2, and MIP-1 $\alpha$ mRNA-all of which require for NF- $\kappa B$ activation. ${ }^{24,25}$ Our preliminary findings are consistent with the findings of Fox and colleagues, ${ }^{26}$ who noted decreased NF- $\kappa$ B activity in Kupffer cells exposed to $100 \mathrm{mM}$ ethanol in culture. In vivo, however, acute ethanol administration or chronic ethanol ingestion followed by acute rechallenge has been associated with enhanced NF- $\kappa \mathrm{B}$ activity in rat brain, ${ }^{27}$ indicating that disparity exists between those observations made in vitro to those made in the in vivo settings. Although these studies suggest ethanol suppresses cytokine mRNA transcription, we cannot exclude a component of ethanol-induced acceleration of cytokine mRNA degradation.

Despite strict calorie-matching of complete liquid diets, ethanol-fed mice experienced modest weight loss during alcohol feeding, whereas control animals gained weight during the experimental period. Disparity in weight gain while on isocaloric diets has been noted previously. ${ }^{18}$ Therefore, it is possible that nutritional factors could con- 
A
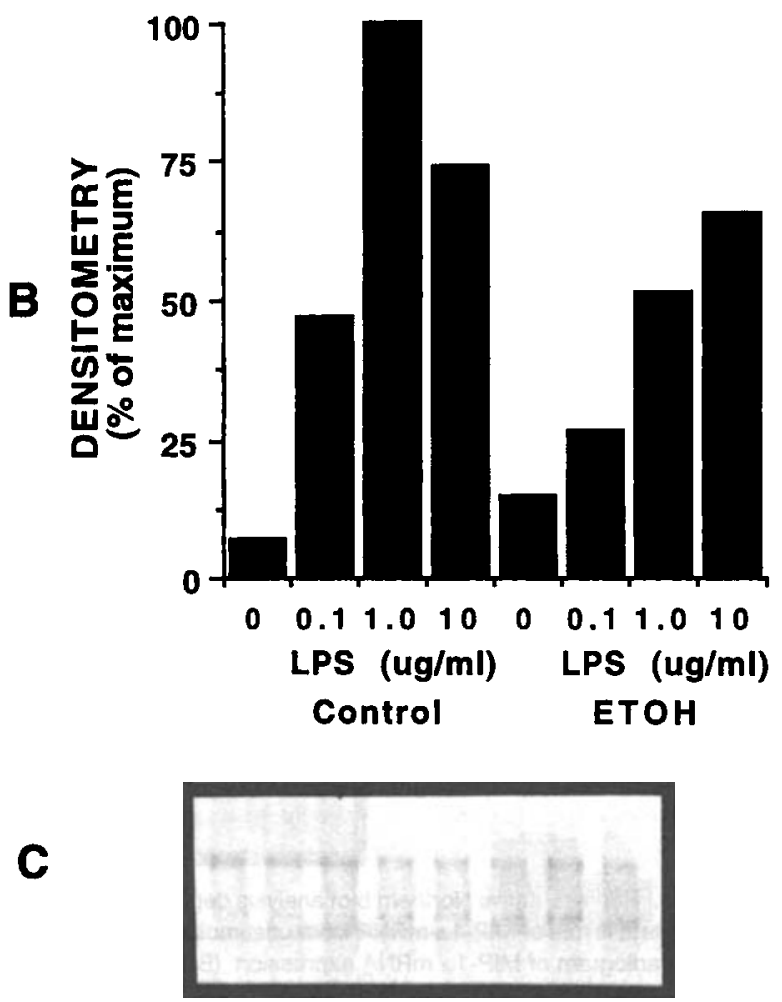

Fig. 4. Representative Northem blot analysis depicting the effect of ethanol on steady-state levels of MIP-2 mRNA from unstimulated and LPS-stimulated AM. (A) Autoradiogram of MIP-2 mRNA expression. (B) Densitometric quantification of the corresponding autoradiogram. (C) The $28 \mathrm{~s}$ and $18 \mathrm{~s}$ rRNA demonstrating equivalent loading of RNA. ETOH, AMs from ethanol-fed animals. Experimental, $n=2$.

tribute to differences in ex vivo cytokine expression. However, this limited degree of malnutrition over a relatively brief time-span is unlikely to account for the effects observed. Furthermore, malnutrition and alcoholism frequently co-exist clinically.

The inhibitory effects of ethanol on AM-derived cytokine expression has important pathophysiological implications. In vivo and in vitro studies in ethanol-treated animals and humans have revealed significant impairments of both neutrophil and AM mobilization and activation..$^{19,28-32}$ Specifically, in vivo studies indicate that short- or long-term ethanol administration decreases neutrophil influx into traumatized skin or rabbit corneas. Moreover, acute ethanol intoxication significantly attenuates neutrophil influx to the lung airspace in response to aerosolized Staphylococcus aureus, Proteus mirabilis, and intratracheally administered LPS. ${ }^{19,31}$ Interestingly, neutrophils recovered from alcoholchallenged human subjects display no abnormalities in the ability to migrate in response to chemotactic stimuli. ${ }^{33}$ Additional studies indicate that alcohol treatment inhibits the ability of neutrophils and/or macrophages to kill bac- terial organisms such as $S$. aureus, $P$. mirabilis, and Legionella pneumoniae. ${ }^{19,21,31}$ Collectively, these observations suggest that defects in leukocyte recruitment and antimicrobial activity may be due to insufficient expression of required chemotactic and activating cytokines. The observation of alcohol-induced changes in TNF- $\alpha$ and chemokine release by activated AMs would readily explain observations made previously. Further studies are required to determine the duration of alcohol effects on ex vivo cytokine expression, as well as effects of alcohol on chemotactic and activating cytokine expression during the evolution of innate and acquired immune responses in vivo.

\section{REFERENCES}

1. Toews GB, Gross GN, Pierce AK: The relationship of inoculum size to lung bacterial clearance and phagocytic cell response in mice. Am Rev Respir Dis 120:559-566, 1979

2. Fels AOS, Cohn ZA: The alveolar macrophage. J Appl Physiol 60:353-369, 1986

3. Le J, Vilcek J: Tumor necrosis factor and interleukin-1: Cytokines with multiple overlapping biological activities. Lab Invest 56:234-248, 1987

4. VanOtteren GM, Standiford TJ, Kunkel SL, Danforth JD, Burdick MD, Abruzzo L, Strieter RM: The expression and regulation of macrophage inflammatory protein 1 alpha by murine alveolar and peritoneal macrophages. Am J Respir Cell Mol Biol 10:8-15, 1994

5. Oppenheim JJ, Zachariae COC, Mukaida N, Matsushima K: Properties of the novel proinflammatory supergene "intercrine" cytokine family. Ann Rev Immunol 9:617-647, 1991

6. Tekamp-Olsen P, Gallegos C, Bauri D, McClain J, Sherry B, Fabre $M$, Van Deventer S, Cerami A: Cloning and characterization of cDNA's for murine macrophage inflammatory protein 2 and its human homologue. J Exp Med 172:911-919, 1990

7. Davatelis G, Tekamp-Olson T, Wolpe SD, Hermsen K, Leudke C, Gallegos C, Coit D, Merryweather J, Cerami A: Cloning and characterization of a cDNA for murine macrophage inflammatory and neutrophil chemokinetic properties. J Exp Med 167:1939-1944, 1988

8. Laichalk L, Kunkel S, Strieter R, Danforth J, Bailie M, Standiford T: Tumor necrosis factor mediates lung antibacterial host defense in murine Klebsiella pneumonia. Infect Immun 64:5211-5218, 1996

9. Brieland J, Remick D, Freeman P, Hurley M, Fantone J, Engleberg $\mathrm{N}$ : In vivo regulation of replicative Legionella pneumophila lung infection by endogenous tumor necrosis factor alpha and nitric oxide. Infect Immun 63:3253-3258, 1995

10. Huffnagle GB, Toews GB, Burdick M, Boyd M, McAllister K, McDonald RA, Kunkel SL, Strieter RM: Afferent phase production of TNF- $\alpha$ is required for the development of protective T cell immunity to Cryptococcus neoformans. J Immunol 157:4529-4536, 1996

11. Greenberger M, Strieter RM, Kunkel SL, Danforth J, Laichalk L, McGillicuddy D, Standiford TJ: Neutralization of MIP-2 attenuates neutrophil recruitment and bacterial clearance in murine Klebsiella pneumonia. J Infect Dis 173:159-165, 1996

12. Huffnagle GB, Strieter RM, Standiford TJ, McDonald RA, Kunkel SL, Toews GB: Efferent phase production of macrophage inflammatory protein-1 $\alpha$ (MIP-1 $\alpha$ ) is required for protective cell-mediated immunity to a pulmonary Cryptococcus neoformans infection. J Immunol 159:318-327, 1997

13. Grove M, Plumb M: C/ESP, NF- $\kappa B$, and c-Ets family members and transcriptional regulation of the cell-specific and inducible macrophage inflammatory protein 1 (immediate-early gene). Mol Cell Biol 13:52765289,1993

14. Matsusaka T, Fujikawa $K$, Nishio $Y$, Mukaida N, Matsushima K, Kishimoto T, Akira S: Transcription factors NF-IL6 and NF- $\kappa$ B synergistically activate transcription of the inflammatory cytokines, interleukin 6 
and interleukin 8. Proc Natl Acad Sci USA 90:10193-10197, 1993

15. MacGregor RR: Alcohol and immune defense. JAMA 256:14741479, 1986

16. Adams HG, Jordan C: Infections in the alcoholic. Med Clin North Am 68:179-200, 1984

17. Nelson S, Bagby G, Summer WR: Alcohol suppresses lipopolysaccharide-induced tumor necrosis factor activity in serum and lung. Life Sci 44:673-676, 1989

18. D'Souza NB, Bagby GJ, Nelson S, Lang CH, Spitzer JJ; Acute alcohol infusion suppresses endotoxin-induced serum tumor necrosis factor. Alcoh Clin Exp Res 13:295-298, 1989

19. Nelson S, Bagby GJ, Bainton BG, Summer WR: The effects of acute and chronic alcoholism on tumor necrosis factor and the inflammatory response. J Infect Dis 160:422-429, 1989

20. Honchel R, Ray MB, Marsano L, Cohen D, Lee E, Shedlofsky S, McClain CJ: Tumor necrosis factor in alcohol enhanced endotoxin liver injury. Alcohol Clin Exp Res 16:665-669, 1992

21. Yamamoto Y, Klein TW, Friedman H: Ethanol affects macrophage production of IL-6 and susceptibility to infection by Legionella pneumophila, in Friedman H (ed): Drugs of Abuse, Immunity and AIDS. New York, Plenum Press, 1993

22. Alak JIB, Shahbazian M, Huang D, Wang Y, Darban H, Jenkins EM, Watson RR: Alcohol and murine acquired immunodeficiency syndrome suppression of resistance to Crytosporidium parvum infection during the modulation of cytokine production. Alcohol Clin Exp Res 17:539544,1993

23. Chirgwin JM, Przybyca AE, MacDonald RJ, Rutter WJ: Isolation of biologically active ribonucleic acid from sources enriched in ribonuclease. Biochemistry 18:5294-5299, 1979
24. Wang P, Wu P, Siegel MI, Egan RW, Billah MM: Interleukin (IL)-10 inhibits nuclear factor $\mathrm{\kappa B}(\mathrm{NFkB})$ activation in human monocytes. J Biol Chem 270:9558-9563, 1995

25. Lenardo MJ, Baltimore D: NF- $\mathrm{kB}$ : A pleiotropic mediator of inducible and tissue-specific gene control. Cell 58:227-229, 1989

26. Fox ES, Cantrell $\mathrm{CH}$, Leingang KA: Inhibition of the Kupffer cell inflammatory response by acute ethanol: NF- $\kappa$ B activation and subsequent cytokine production. Biochem Biophys Res Comm 225:134-140, 1996

27. Ward RJ, Zhang Y, Crichton RR, Piret B, Piette J, de Witte P: Identification of the nuclear transcription factor $N F \kappa B$ in rat brain after in vivo ethanol administration. FEBS Lett 389:119-122, 1996

28. Hoek JB, Rubin E: Alcohol and membrane-associated signal transduction. Alcohol Alcohol 25:143-156, 1990

29. Leibowitz HM, Ryan W, Kupferman A, Vitale JJ: The effect of alcohol intoxication of inflammation of the cornea. Arch Opthamol 1995: 723-725, 1995

30. MacGregor RR, Safford M, Shalit M: Effect of ethanol on functions required for the delivery of neutrophils to sites of inflammation. J Infect Dis 157:682-689, 1988

31. Astry CL, Warr GA, Jakab GJ: Impairment of polymorphonuclear leukocyte immigration as a mechanism of alcohol-induced suppression of pulmonary antibacterial defenses. Am Rev Respir Dis 164:113-117, 1983

32. Guarneri JJ, Laurenzi GA: Effect of alcohol on the mobilization of alveolar macrophages. J Lab Clin Med 72:40-51, 1968

33. Gluckman SJ, Dvorak VC, MacGregor RR: Host defense during prolonged alcohol consumption in a controlled environment. Arch Intern Med 137:1539-1543, 1977 